Article

\title{
Between Idealism and Pragmatism: Social Policies and Matthew Effect in Vocational Education and Training for Disadvantaged Youth in Switzerland
}

\author{
Delia Pisoni \\ Swiss Graduate School of Public Administration (IDHEAP), University of Lausanne, 1015 Lausanne, Switzerland; \\ E-Mail: delia.pisoni@unil.ch
}

Submitted: 11 April 2018 | Accepted: 31 August 2018 | Published: 28 September 2018

\begin{abstract}
Since the mid-1970s, research shows that less-disadvantaged individuals more frequently access social policy schemes when compared to their more-disadvantaged counterparts, a phenomenon called the Matthew effect. Through two indepth case studies, based on 60 semi-directive interviews, and document analysis, this study aims to more fully understand the mechanisms leading to a Matthew effect in Swiss Vocational Education and Training (VET) programmes for disadvantaged youth. Indeed, education is key to post-industrial labour markets access, and VET appears to facilitate schoolto-work transitions. A Matthew effect in this policy field might thus lead to particularly detrimental repercussions, and public authorities should be especially eager to contain it. Nevertheless, findings show that, under certain conditions, decision-makers push frontline-workers into cream-skimming practices, causing a Matthew effect. Additionally, structural challenges also lead to a Matthew effect, highlighting the general difficulty of the very mandate: (re-)inserting highly disadvantaged individuals into selective markets. Indeed, in contexts of tight public budgets, service oriented modern Welfare States tread a fine line between empowering and prioritising beneficiaries. Dealing with complex target groups, it seems crucial whether the rationale driving public authorities is more oriented towards credit-claiming or problem-solving: the former increasing and the latter decreasing the incidence of Matthew effects.
\end{abstract}

\section{Keywords}

disadvantaged youth; education; Matthew effect; social policy; Switzerland; Vocational Education and Training; welfare

\section{Issue}

This article is part of the issue "Vulnerable and Disadvantaged Groups: On the Margins of the Welfare State?", edited by Inger Lise Skog Hansen and Tone Fløtten (Fafo Institute for Labour and Social Research, Norway).

(C) 2018 by the author; licensee Cogitatio (Lisbon, Portugal). This article is licensed under a Creative Commons Attribution 4.0 International License (CC BY).

\section{Introduction}

More than four decades have lapsed since 1975 when Herman Deleeck introduced the notion of a Matthew effect in social policy research. This concept describes a situation in which the least-disadvantaged individuals among a targeted group are more able to benefit from social policy schemes than their more-disadvantaged counterparts. Thus, it allows for a depiction of the various means in which social policy particularly favours upper social-classes (Deleeck, 1979) or, more generally, less-disadvantaged individuals among a target group. As within-country disparities have increased over the last years, this principle remains an interesting object of study. Recent research in social policy also highlighted the existence of a Matthew effect in interventions aimed at facilitating labour market participation, particularly focusing on access to childcare services (e.g., Bonoli \& Champion, 2015; van Lancker \& Ghysels, 2012), or on the broader functioning of the social investment approach (Bonoli, Cantillon, \& van Lancker, 2017; Cantillon, 2011). Needless to say, a Matthew effect can significantly impact the life-chances of the most vulnerable individuals, while affecting public finances due to higher social expenditures and forgone public revenue. Therefore, it is in the interest of public policy to contain it as much as possible.

As education has become a crucial asset for labour market integration in modern knowledge societies, it is particularly important to limit a Matthew effect in this policy field. Indeed, structural changes such as tertiari- 
sation, technological evolution and globalisation have driven post-industrial economies towards an increasingly skilled workforce (e.g., Bonoli, 2013). Young adults lacking post-compulsory education are a particularly vulnerable group, facing great employment difficulties and a high risk of poverty (López Vilapana, 2013). Moreover, long unemployment spells at a young age can leave longlasting scarring effects (e.g., Bell \& Blanchflower, 2010). Consequently, rapid youth integration into labour markets is crucial, and post-compulsory education seems a promising avenue for increased chances on the labour market. Vocational Education and Training (VET) systems, in particular dual-VET, which combines in-school theoretical education with on-the-job practical training (apprenticeships and dual-VET are used interchangeably), are often praised for facilitating school-to-work transitions (e.g., Salvisberg \& Sacchi, 2014; Stalder, 2012). Political efforts to support VET integration are therefore an important tool to increase disadvantaged youth's chances on the labour market. Yet, it is crucial that they manage to reach out to the most-disadvantaged youth, as dual-VET access is generally challenging, and the moredisadvantaged face greater access difficulties (e.g., Häfeli \& Schellenberg, 2009).

A Matthew effect in dual-VET programmes for disadvantaged youth might therefore be particularly detrimental, leading to long-term repercussions on individual well-being and on welfare states, further marginalising already highly vulnerable persons. Previous studies focused e.g., on a French social integration programme for disadvantaged youth (Gomel, Issehnane, \& Legendre, 2013), on VET programmes in Belgium (Nicaise, 2000), or on training and employment programmes for disadvantaged individuals (Nicaise \& Bollens, 1998). The present research differs from those studies by focusing on a Matthew effect in dual-VET programmes for disadvantaged youth. The rather narrow focus pursued in this study is due to its presumed integration potential and consequent political salience. Given dual-VET's strength in facilitating school-to-work transitions, such programmes presumably result in more opportunities for youth labour market integration-while training is a broad term, inclusive of diverse activities (e.g., language or computer courses) and yielding highly diverse impacts, dual-VET programmes are highly specific and fairly rare among activation policies. Moreover, given the risk of substantial repercussions on public finances through failed youth labour market integration, Matthew effect containment in this policy field should be particularly relevant to policy makers. Yet, difficult dual-VET accessibility for disadvantaged youth implies that some degree of a Matthew effect is likely present. Against this backdrop, this article is guided by questions of why and how a Matthew effect occurs in training programmes for disadvantaged youth. This research aims to contribute to the understanding of the Matthew effect through a holistic investigation of the contributing mechanisms in two Swiss dual-VET programmes.
The article is structured as follows. First, background information and research approach are introduced (Section 2). Second, the analytic lens is presented, highlighting key actors and crucial systems affecting access to the studied measures (Section 3). Third, a synthesis of results is explained, then illustrated through relevant excerpts from the empirical data (Section 4). This section is divided according to the two detected mechanisms leading to a Matthew effect in the studied cases: as a consequence of the political mandate (Section 4.2.1), and due to cream-skimming incentive structures for frontline workers (Section 4.2.2). Discussion and conclusion follow.

\section{Background and Research Approach}

Switzerland offers interesting research opportunities for investigating the different mechanisms leading to a Matthew effect in youth VET programmes. The federal structure and a generally high degree of local discretion lead to a variety of programmes embedded in cantonal contexts, while the general reference to the VET system, of federal competence, is nationally uniform. Dual-VET is quite popular in Switzerland: annually, two-thirds of youth opt for a VET upper-secondary education, with a majority opting for dual-VET (Staatssekretariat für Bildung, Forschung und Innovation [SBFI], 2018, p. 10). The proximity of dual-VET to labour market requirements, in terms of skills and workforce, is often associated with the comparatively low youth unemployment rate in Switzerland (SBFI, 2018, p. 4). Indeed, the nationally recognised VET certificates represent a valuable asset for integration within the Swiss labour market.

To holistically explore the mechanisms and reasons engendering a Matthew effect, I rely on two in-depth, embedded case studies (Yin, 2009/2013, p. 50). Each case study represents a Swiss cantonal (regional) measure aimed at increasing disadvantaged youth's chances on the labour market by supporting their achievement of a VET certificate. For each case, the different groups of key actors represent the units of analysis. Selected relative to their influence on the odds of youth access to the measures, these are politico-administrative actors (designing, steering and managing the policies), frontline workers (implementing the programmes), the targeted youth (defining the degree of integration difficulty), and other crucial actors relative to each case. The main data source is a corpus of 60 semi-structured faceto-face interviews, lasting between 30 and 90 minutes, with 63 key actors. For the first case 39 interviews with 40 persons were conducted, and for the second (smaller) case, 21 interviews with 23 persons were conducted. Table 1 offers an interview overview, clustered by key actor group. Analysis of the fully self-transcribed interviews was performed using MAXQDA, and draws on grounded theory (Glaser \& Strauss, 1967). Aiming at fully understanding a phenomenon, grounded theory seems particularly appropriate for the present study. In order to se- 
Table 1. Interviews clustered by group of actors.

\begin{tabular}{|c|c|c|c|c|}
\hline Group Of Actors & Function (Citation Code) & $\begin{array}{l}\text { No. Interviews; } \\
\text { No. Interviewees }\end{array}$ & Function (Citation Code) & $\begin{array}{l}\text { No. Interviews; } \\
\text { No. Interviewees }\end{array}$ \\
\hline & \multicolumn{2}{|c|}{ Case 1-Large Francophone Canton } & \multicolumn{2}{|c|}{ Case 2-Small Germanophone Canton } \\
\hline \multirow[t]{2}{*}{$\begin{array}{l}\text { Politico- } \\
\text { Administrative } \\
\text { Actors }\end{array}$} & $\begin{array}{l}\text { Cantonal level: } \\
\text { Design and steering } \\
\text { (POLADMIN1-CANT-I \& II); }\end{array}$ & $3 ; 2$ & $\begin{array}{l}\text { High civil servant: } \\
\text { Design and steering } \\
\text { (POLADMIN2-I) }\end{array}$ & 1 \\
\hline & $\begin{array}{l}\text { Municipal level: } \\
\text { Local implementation } \\
\text { management } \\
\text { (POLADMIN-MUN1-I \& II) }\end{array}$ & $3 ; 2$ & $\begin{array}{l}\text { Support-group members: } \\
\text { Various actors involved in } \\
\text { designing the measure, } \\
\text { now consultative function } \\
\text { (POLADMIN2-II to VII) }\end{array}$ & 6 \\
\hline \multirow[t]{2}{*}{$\begin{array}{l}\text { Street-Level } \\
\text { Bureaucrats }\end{array}$} & $\begin{array}{l}\text { Social workers: } \\
\text { Providing social support to } \\
\text { the youth before accessing } \\
\text { the programme } \\
\text { (SLB-SW1-I to X) }\end{array}$ & 10 & $\begin{array}{l}\text { Professionals working for } \\
\text { the contracted } \\
\text { organisation, participating } \\
\text { to design and steering } \\
\text { (SLB2-I to IV) }\end{array}$ & 4 \\
\hline & $\begin{array}{l}\text { SIM workers: } \\
\text { Socio-professional } \\
\text { (re)integration experts, } \\
\text { contracted to support youth } \\
\text { to find a solution } \\
\text { (SLB-SIM1-I to XIV) }\end{array}$ & $11 ; 14$ & & \\
\hline $\begin{array}{l}\text { (Potential) Policy } \\
\text { Recipients }\end{array}$ & $\begin{array}{l}\text { 18-25-year-olds at the benefit } \\
\text { of social assistance, without } \\
\text { accomplished post- } \\
\text { compulsory education, } \\
\text { enrolled in a SIM } \\
\text { (YOUTH1-I to X) }\end{array}$ & $10 *$ & $\begin{array}{l}\text { 15-24-year-olds risking to } \\
\text { fail post-compulsory } \\
\text { education transition due } \\
\text { to multiple problematics, } \\
\text { enrolled in the measure } \\
\text { (YOUTH2-I \& II) }\end{array}$ & 2 \\
\hline Others & $\begin{array}{l}\text { Member of the organisation } \\
\text { accompanying the youth } \\
\text { enrolled in the programme } \\
\text { (ADD1-I) } \\
\text { Employee of a municipal } \\
\text { specialised insertion unit } \\
\text { (ADD1-II) }\end{array}$ & 2 & $\begin{array}{l}\text { Professionals of } \\
\text { institutions entitled to } \\
\text { announce youth } \\
\text { (ADD2-I to VIII) }\end{array}$ & $8 ; 10$ \\
\hline Total & & $39 ; 40$ & & $21 ; 23$ \\
\hline
\end{tabular}

Note: * Including a 17-year-old, thus ineligible for social assistance.

lect the data useful to holistically understand the phenomenon, different analytical rounds aim to progressively lead the analysis to a higher theoretical abstraction from the empirical data: in a first round of coding (open coding), relevant segments of data are labelled; in a second one (axial coding), the codes are placed in relationship with one another; in the last round (selective coding), code categories are identified on the basis of clustered codes (Braun \& Clarke, 2013, pp. 211, 214). Desk research of primary and secondary sources complements the interviews.

Generally, the aim was to reconstruct the mechanisms leading to a Matthew effect through a "backward mapping' approach: first identifying where a Matthew effect occurs, then reconstructing the rationale underlying the Matthew-effect-inducing strategies. Questions varied between group and stage of the research. Interviews investigated, for instance, the policy design definition and rationale (politico-administrative actors), working strategies and challenges (frontline workers) and the difficulties of finding an apprenticeship post (youth). To identify a Matthew effect, criteria determining restricted programme access, as derived from interviews and document analysis, were compared to the notion of disadvantage. If the information was corresponding, a Matthew effect was identified. Since the focus of the study is to 
identify the underlying mechanisms to, and not whether there is a Matthew effect, a precise measure of the effect, barely possible, is not crucial. The concept of disadvantage employed in this research is relative to dualVET access, since this is determinant to access both programmes. This draws on both relevant literature (see Section 3) and interviewee accounts, in order to address local peculiarities.

The first case, implemented in a large Frenchspeaking canton, targets young adults (18-25-year-olds) benefiting from social assistance, who have not completed upper-secondary education (for a more in-depth analysis of this case see Pisoni, in press). This is a unique programme resulting from local discretion, as social assistance is a cantonal competence in Switzerland. To enhance labour market (re-)integration, the programme offers individualised support throughout apprenticeship, and a scholarship covering training and living expenses. To be eligible, youth from the target group need to have found a training opportunity. Several Social Insertion Measures (SIMs) have been contracted to support them in this search. SIMs are mainly non-profit organisations mandated to help these youth to find a mid- to long-term solution, with preference for an apprenticeship.

The second case is a federally initiated programme intended to enhance the number of youth completing upper-secondary education. The central government issued broad guidelines, and financed the initial phase, followed by a regressive financing model with cantons eventually assuming the financial burden. Since implementation was cantonal and voluntary, cantonal programmes developed in different directions. The selected measure, implemented in a small, affluent Swiss-German canton, aims to support youth (15-24-year-olds) at risk of failing the post-compulsory-school transition due to multiple difficulties. It offers an individualised support throughout this transition and throughout VET. To avoid a revolving-door effect-that is, a fragmented treatment according to agencies' tasks instead of appropriate holistic support-a reference person refers youth to existing support options in order to treat the multiple problematics as a combination of measures, rather than treating problems separately. Eligibility is based on youth's intention, and capability of pursuing VET. Youth need to get announced through an institution (e.g., schools, unemployment office, social assistance). Implementation is delegated to a private association, framed as a public-privatepartnership.

Selection of the first case was based on the assumption of a Matthew effect through comparison of low access rates (ca. $20 \%$ ) to the high success rate $\left(65 \%^{1}\right)$. It was presumed that the less-disadvantaged youth among the target group primarily access the programme. This made it an excellent case to explore the dynamics which lead to a Matthew effect. The second case was selected due to its similar objective, yet different cantonal context: different management arrangements, and a more dynamic apprenticeship market, ${ }^{2}$ potentially lowering the access threshold for the most-disadvantaged youth. With access rates around 78\% (2009-2017), and success rates around $47 \%^{3}$ (2010-2017), tendency towards a Matthew effect is less apparent.

\section{Accompanying Disadvantaged Youth to Integrate a Selective Market}

The organisational field and Street-Level Bureaucracy emerged as a useful theoretical framework, as empirical insights quickly highlighted the importance of actors' behaviours, substantially shaped by pressures originating from the organisational and broader contextual framework. Combining strategic analysis of organisations (Crozier \& Friedberg, 1977/2014), and Street-Level Bureaucracy theory (Lipsky, 1980/2010) offers a particularly relevant analytic lens for the present study, as both theories aim at exploring and highlighting the role and diversity of informal norms and practices in public organisations (Buffat, 2016, p. 159), approaching the issue from different angles. While strategic analysis of organisations focuses on the interaction between the relevant groups of key actors as well as between actors and the system(s) steering their actions, Street-Level Bureaucracy zooms in on frontline workers, emphasising structural constraints and challenges stemming from their working conditions (Brodkin, 2012, pp. 941-942).

According to strategic analysis of organisations, in a collective action context, actors' strategies are mainly constrained by two factors: first, the behaviour of other actors participating in the collective action, and second, the systems delimiting actors' behavioural options. Rationality, indeed, might not be evident nor necessarily conscious or intentional, but always makes sense in context and in function of other actors' 'moves' (Amblard, Bernoux, Herreros, \& Livian, 1996/2005, p. 23). Relative to the studied cases, interviewee groups denote groups of key actors. In terms of systems, actors' behaviour in both cases seem shaped by dual-VET and by the politico-administrative framework. Relative to the former, the apprenticeship offer in Switzerland relies on the economy (Häfeli \& Schellenberg, 2009): employers are free to choose whether and whom to train. Since employers must comply with market principles, they generally try to contain training costs by selecting most trainable youth (Di Stasio, 2014). The allocation of apprenticeships, therefore, relies substantially on market principles comprehending inherent competition and selection logics. Consequently, integration into dual-VET markets is challenging for many youth,

\footnotetext{
${ }^{1}$ Youth succeeding throughout apprenticeship. Success rate at the final exam is similar to the overall cantonal rate (80\%).

2 Dual-VET is more entrenched in German-speaking than Latin Switzerland. Moreover, it strongly depends on labour markets, thus, in economically strong contexts, dual-VET is also more dynamic.

${ }^{3} 42 \%$ accomplished VET; $5 \%$ of cases were ended prematurely because support was no longer needed.
} 
more so for disadvantaged ones. The literature highlights several factors influencing apprenticeship market opportunities. On the individual level, crucial features include cognitive and soft-skills; compulsory-school classtrack; ${ }^{4}$ socio-economic and migration background; nationality; informal networks; working virtues and gender (Camilleri-Cassar, 2013; Di Stasio, 2014; Häfeli \& Schellenberg, 2009; Hupka \& Stalder, 2004; Liebig, Kohls, \& Krause, 2012; Meyer, 2009; Perriard, 2005; Protsch \& Solga, 2015; Solga, 2015). Meeting apprenticeship market requirements when struggling with compound problematics might be particularly challenging. Indeed, people in 'complex needs' situations face multiple interlocking problematics, spanning from health to social issues. This term addresses both breadth and depth of needs, i.e., variety and severity of needs (Rankin \& Regan, 2004, pp. 7-8). The way the studied programmes address youth's complex needs in order to help them integrate into the dual-VET market is a determinant of a Matthew effect incidence.

The politico-administrative framework is generally shaped by a context of 'permanent austerity' (Bonoli, 2013 , p. 3), inducing cost-containment attempts. It comprehends two components: activation policies and public management. From an administrative perspective, the first case adheres to New Public Management (NPM) principles, while the second, post-NPM. NPM generally aims to improve public sector effectiveness and efficiency, reducing public expenditures and improving managerial accountability (Christensen \& Laegreid, 2011/2013, p. 1). Performance management and output are key elements (Jun, 2009, p. 162). It also promotes contractualism, emphasizing well-defined, short, fixed-term contracts, with monetary incentives (Boston, 2011/2013, pp. 20-21). The first case contains several NPM features: governance is highly verticalised, with substantial distance between the principal-politicoadministrative powers defining the policy design-and agents-lower administrative levels in charge of implementing (aspects of) the policy. Moreover, public authorities contracted several SIMs for the delivery of wellspecified outputs. Accountability and assessment are result-based: contracts are annually renegotiated on the basis of a predetermined success rate.

Post-NPM pursues a more holistic strategy, relying on insights also from other social sciences, instead of a pure economic vision. It pursues better usage of scarce resources by creating synergies "bringing together different stakeholders in a particular policy area and to offer citizens seamless rather than fragmented access to services" (Christensen \& Laegreid, 2007/2009, p. 10). Instead of quasi-market forces, it emphasises networkbased self-regulation (Dent, 2005, p. 632), coordination, cooperation, clearly-defined role relationships and public-private-partnerships (Jun, 2009, p. 163). The second case follows post-NPM principles: implementation is delegated to a single organisation, already active in supporting disadvantaged youth during apprenticeship, in the form of a public-private-partnership. A support group composed of key actors from municipal schools and cantonal offices involved with youth was appositely created to buttress the organisation. Accountability and assessment are process-based, relying on the number of enrolled youth. The annually negotiated partnership determines how many youth will be financed by the cantonal department in the following year.

From a political perspective, both programmes are activation policies with a social investment approach: to activate youth on the labour market by investing in their education and training. Indeed, modern welfare states increasingly focus on activating beneficiaries, along with the more traditional task of securing income, aiming to (re-)insert benefit claimants into the labour market through various strategies. To meet increasing skill requirements of knowledge economies, social investment strategy aims to invest in people's human capital. A more individualised service resulting from activation policies sounds promising for responding to the challenge of supporting persons with complex needs. However, the focus on activating beneficiaries comes with an emphasis on their responsibility. In exchange for benefits, beneficiaries must satisfy certain activation principles. This can have an empowering effect, but it also "makes access to welfare benefits more constraining and selective" (Dif-Pradalier, Rosenstein, \& Bonvin, 2012, p. 1). The increased selectivity and emphasis on self-responsibility may make it particularly hard for persons struggling with complex needs to comply with activation expectations.

As social policy is increasingly service orientated, the quality of the accompaniment beneficiaries receive highly depends on frontline practices. In Lipsky's terms, the way public policy reaches the population, affecting people's lives, is strongly influenced by how frontline workers transform policies into practice. Thus, Lipsky's analytic framework leads to a more precise understanding of the implications of a particularly crucial group of actors on a Matthew effect. In constant contact with citizens, and working in situations requiring responses to human dimensions, Street-Level Bureaucrats (SLBs) enjoy a certain discretion in executing their jobs (Lipsky, $1980 / 2010$, pp. 3, 15). Accompanying youth with complex needs to (re-)integrate into a selective apprenticeship market is an intricate task. The target group is highly heterogeneous, each individual carrying a unique set of challenges linked to personal situation and context. It is therefore crucial that frontline workers are capable of adapting their working strategies to each individual situation. Yet, a major dilemma in public services is perpetual resource scarcity (Lipsky, 1980/2010, pp. 33-39). Consequently, the work structure does not allow frontline workers to perform the job in its ideal conception (Lipsky, 1980/2010, pp. xi-xii, xvii, 3). To deal with this incapa-

\footnotetext{
${ }^{4}$ In differentiated education systems, pupils are divided into different tracks during lower-secondary education, affecting upper-secondary education options.
} 
bility of best treating each individual case, SLBs, relying on their discretionary power, may develop coping strategies and working regularities. A strategy for attaining a manageable workload is to re-categorise and differentiate 'clients' in function of the likelihood of their administrative success, i.e., cream-skimming (Lipsky, 1980/2010, p. 107). To address the complexity of each individual situation in a context of scarce resources becomes particularly challenging. The degree to which SLBs can extend the quality and individualisation of their support greatly depends on their working conditions. These conditions are largely determined by politico-administrative actors through the general design of the policy. Particularly important are the access conditions to a measure, and frontline worker assessment criteria. The former determines the difficulty for the target group to access a programme, and the latter shapes the incentive structure addressed to frontline workers and contributes to determining the degree of frontline worker discretion.

\section{Further Marginalising the Most-Disadvantaged?}

In the following sections, the two mechanisms leading to a Matthew effect are presented: in both cases, a Matthew effect stems from the political mandate (Section 4.1); only in the first case do the politicoadministrative rationale and the resulting policy design again trigger this effect (Section 4.2).

\subsection{The Political Mandate}

A first Matthew effect is driven by the very mandates of the two programmes: integrating highly disadvantaged youth into a selective apprenticeship market. Access to this market is central in both policies' eligibility criteria: having found a training opportunity (first case) or being motivated and capable of following VET (second case). Yet, while targeting disadvantaged youth, neither policy addresses the market's selective nature. Empirical findings highlight how the youth under consideration are generally rather distant from that market. According to several interviewees' accounts (across different groups), many youth cumulate several features highlighted by the literature as hampering VET integration, e.g., migration background, low class-track, and weak cognitive- and soft-skills. Additionally, their complex needs may absorb them to the point of (temporarily) blank out longer-term plans such as education, as their compound struggles often result in unstable life situations. Housing problematics are emblematic to illustrate this: when housing problematics are present, they become central, making it particularly difficult to focus on education or training. Interviewees often cited housing issues in conjunction with family problematics, which are crucial in both cases. Even when housing is guaranteed, lack of familial backing generally leaves youth without support throughout the delicate transition phase. Another major and increasing problematic in both cases are health issues: drug use and, particularly, psychological issues. The lack of a supportive home increases the struggle of addressing such problematics. This succinctly illustrates the interconnection between different problematics and that, in situations of complex needs, "the total represents more than the sum of the component parts" (Rankin \& Regan, 2004, p. 7).

Relative to the first case, the following citations illustrate how youth's complex needs hamper their apprenticeship market integration, the precondition for programme access:

There are youth who start from so low, who face so many difficulties, that if possible it will be way later, maybe two, three years later it will be possible to imagine [their integration]. Because that youth will be in hell. (POLADMIN-MUN1-II)

We have rather few youth who are sufficiently ready to enter an apprenticeship....There are substance abuse, psychological problems too, which makes some really take a long time to enter VET. (SLB-SW1IV; emphasis added by the author)

The literature further highlighted that people with complex needs "may be 'defined out' of the remit of services because they are assessed as being 'too complex' or 'too challenging' for the service" (Rosengard, Laing, Ridley, \& Hunter, 2007, p. 44; see also Nicaise, 2000). Indeed, in the second case, eligibility criteria based on will and capacity of following VET excludes the most-disadvantaged youth from the target group. The following citations illustrate this well:

There are some who are not accepted [to the programme] because the chances of success are practically zero...because you cannot suppose that with a good support they will manage to accomplish an apprenticeship. (POLADMIN2-V; emphasis added by the author)

They take on the cases where they see that it's fine, they can do something, whereas the very difficult ones, which are highly complex from the beginning, those they maybe have to leave aside for the moment, because they actually have the mandate-the measure is relative to VET, not to the general social context...so it's necessary to delimit it a bit, and that's also in the arrangement [with the cantonal department], that it has to be clearly VET oriented, and that this delimitation needs to take place. (POLADMIN2-I; emphasis added by the author)

Consequently, the structural difficulty of integration into the apprenticeship market for the most-disadvantaged youth leads to better access for less-disadvantaged youth not only to the apprenticeship market, but also to the programmes. In both cases, the combination of the mandate and politically unaddressed structural chal- 
lenges (selectivity of the VET market) induces, therefore, a Matthew effect.

\subsection{Between Credit-Claiming and Problem-Solving}

To understand the way frontline workers address individual's complex needs, frontline practices must be analysed in the light of working conditions. It is particularly necessary to comprehend the incentive structure steering their actions. These are largely shaped by the politicoadministrative framework and by the political salience of the respective policies, defining the rationale underlying policy design choices. High political salience and a governance close to political powers in the first case, led to an incentive structure predominantly driven by politico-administrative framework, emphasising activation and NPM. The underlying rationale in this scenario tends towards a credit-claiming approach (Section 4.2.1). With low political salience and governance oriented towards the operative level in the second case, individual challenges of integrating within the VET system were also highlighted. The underlying rationale in this scenario tends towards problem-solving (Section 4.2.2). Creditclaiming rationale resulted in a more restrictive incentive structure focused on clear-cut results, triggering a Matthew effect. A problem-solving approach allowed for more levy to SLBs to address individual difficulties, avoiding a Matthew effect. The following sections illustrate the case-specific mechanisms for understanding whether a Matthew-effect-inducing incentive structure is present.

\subsubsection{Case 1: Credit-Claiming Orientation}

The first programme in this article, a flagship policy, was highly politicised from inception. Broad political support was crucial to ensure parliament continued to allocate the necessary, substantial resources. This led to a creamskimming-inducing policy design for frontline workers tasked with helping youth find an apprenticeship (SIM workers). ${ }^{5}$ Cream-skimming candidates at the entrance of the measure increases probability of successful results, ensuring political support.

Annual SIM contracts with the cantonal department are renewed based on the achievement of a requested success rate. Such conditions make it difficult to properly address youth's complex needs, as the tendency towards measuring public service outputs "may have detrimental impact on service willingness to work with clients with multiple and/or complex needs" (Rosengard et al., 2007, p. 23). Since for most SIMs the contract with the cantonal authority is financially vital, they need to comply with the assessment criteria, even at the expense of their organisational goal, i.e., to support struggling youth. Thus, to ensure organisational survival by preserving the contract, SIM workers cream-skim candidates, i.e., invest more re- sources in the youth already closer to the market. Consequently, a Matthew effect is induced.

In a context driven by an activation focused social investment approach and NPM principles, clear-cut successful results portraying the allocated budget as an investment into participants' activation is key to achieving the necessary political support. In the following citation, a high-ranking civil servant explains how political support was initially garnered via a successful pilot project:

The political context was favourable thanks to the results obtained [from the pilot project], because at the beginning it wasn't so favourable, it was like a bet at the beginning....Then, thanks to these successes, the right as well as the left has applauded the results of this programme and since then there is a big uniformity concerning the way of interpreting its results and success, it then didn't pose problems anymore at the political level. It really appeared as an investment. (POLADMIN-CANT1-I; emphasis added by the author)

To ensure the image of efficient resource use in terms of activation (measured by the number of enrolled youth succeeding throughout VET) and thus to secure political support, one strategy is to select the good risks at the entrance of the measure, as the following citations underline:

I think that the force of this programme is that we don't enrol someone who we know will fail. (POLADMIN-MUN1-II)

I think that [the criteria to access the programme] is really all those who are capable to follow and have the potential. This is why we often say that it is a bit the cream of our clients who we send to the programme. Well, it is for all those for whom the problems are not an obstacle to enter it or to follow it. (POLADMINMUN1-I; emphasis added by the author)

To satisfy the necessity of filtering for low risk candidates, the policy design embedded an incentive structure inducing frontline workers to cream-skim candidates. The following citation of a high-ranking civil servant shows the calculation behind this incentive structure:

The preparatory measures are evaluated according to results. Not according to how they do the job, but according to the results they achieve, and this for me is very important. Because I want them to filter: I prefer that the youth are reoriented towards more adequate measures, instead of staying here and have one failure after another. (POLADMIN-CANT1-I)

Several elements of the incentive structure drive creamskimming practices. First, the contract is renewed on the

\footnotetext{
${ }^{5}$ Contracted to perform activities on behalf of government agencies, SIM workers can be considered SLBs despite working for private organisations (see Smith \& Lipsky, 1993, p. 13).
} 
basis of the satisfaction of a success rate of $50 \%$. Given the general distance of the youth from the VET market, it is much easier to achieve this success rate by focusing on the youth already closer to the market. Tellingly, an increase of the requested success rate from $20 \%$ to $50 \%$ also increased cream-skimming practices as a SIM worker states in the following citation:

However, there is also a creaming which is done. We...hm...it is difficult to say...we try to avoid it on a day-to-day basis, but it is clear that for instance today we will faster say, 'currently it is not yet possible [to insert this youth], this leads nowhere'. Whereas actually before, when we were still at $20 \%$ [of success rate] we could take more time to accompany the youth to see if there still is a change which can be done and so on. But now, we are anyhow constraint, yes it is clear, actually we say more quickly, 'well, there, pfff, it...it won't happen'. (SLB-SIM1-XI; emphasis stressed by the speaker)

Particularly relevant in this respect is the following citation from one of the few SIMs financially independent from the welfare department and, therefore, not subject to its assessment criteria:

What might also be interesting is that in our measure, we will not be...how to say, measured on results with a percentage of success, so, eeehm, we have quite lowthreshold youth: we do not select the good risks. (SLBSIM1-XIV; emphasis added by the author)

Second, the contract is renewed annually. However, the complexity of the situations for most of these youth are often not resolved quickly. For a youth to become 'trainable', more urgent problems may need to be initially addressed. Thus, this time-frame can be restrictive for readying the most-disadvantaged to (re-)integrate into the apprenticeship market:

It takes time. Whereas in the programme it should go fast so that they quit social assistance. But I have rarely seen that it goes fast actually...because if it would go fast, they wouldn't be at social assistance. (SLB-SW1-V)

Third, some SIMs have direct relationships with employers. This allows them to better support the youth in obtaining an internship or, ideally, an apprenticeship. For these youth, selection on the basis of their dossier is difficult. Internships represent a valuable tool for proving suitability and trainability to employers. Through these direct relationships, SIMs also play the role of the youth's guarantors, encouraging employers to give them a chance despite less-than-ideal dossiers. However, these relationships are extremely resource-intensive for SIMs to build and maintain. Consequently, for preservation of these essential contacts, SIMs carefully select can- didates to send to these firms. The most-disadvantaged youth represent a potential threat to the relationship, and subsequently benefit less from this resource:

This is what is difficult for us, that sometimes the youth didn't show-up or there were issues, so we lost the link [to the employer]. Recently it happened to us and it is quite difficult already to get this link and then all the sudden, hopp! So sometimes we have to choose according to the type of firm whom we place, well, choose...is a big word, but to pay attention in order to preserve our contact. (SLB-SIM1-X)

Therefore, the necessity of ensuring political consensus, in an activation driven social investment and NPM framework, seems to induce goal displacement: emphasis on supporting youth in overcoming their obstacles to activation, shifts towards credit-claiming based on youth activation results. This results in a Matthew effect-inducing incentive structure.

\subsubsection{Case 2: Problem-Solving Orientation}

The second programme was practically non-politicised because the appeal for the measure and its initial financing came through the federal government. When the canton assumed control of its financing, the programme had already proven itself and was fully running; substantial initial investments were not necessary. Indeed, despite coinciding with a difficult moment in terms of cantonal finances, the programme was not debated in parliament, but simply taken over, (though with a restricted budget due to generalised financial cuts). The minor political salience allowed actors to ignore creditclaiming ploys, and to retain focus on the core addressed problem: supporting youth with complex problematics throughout their transition. The cantonal administration, the support group, and the contracted organisation conjointly defined the policy design. This allowed to keep the contracted organisation's goal (to support disadvantaged youth throughout transition) central during this key phase and to integrate frontline challenges into the policy design. Therefore, while activation remains a central goal, work structures allow the core issue to be better addressed.

The relationship between the organisation and the cantonal department is based on an annually negotiated agreement between the two parties, determining the number of youth financed by the canton. The contract is determined by process-based assessment: instead of clear-cut activation-based results, the number of enrolled youth is most relevant. If these numbers are less than agreed upon, the cantonal financial contribution would be revised accordingly, but the partnership is not interrupted. Given the process assessment, though the contract is renewed annually, the support offered to youth is not bound to this time-frame. These working conditions leave frontline workers much more leeway in addressing the individual compound difficulties. 
In the following citation a high-ranking civil servant illustrates the measure's low political salience, and how this enables focus on the core problematic rather than providing clear-cut outputs which are difficult to measure:

I'm convinced that we don't have an inexpensive but a good measure....I simply consider the context and evaluate the general cantonal situation and I have to say that it works, and the measure contributes to this-although I cannot prove how much the measure contributes to the general good situation, but it certainly is an important contribution.... Of course it would be difficult if a political questioning would come: we have to tell the exact output, how would the situation be if we hadn't the measure, what would we lack....Those are difficult questions, but they don't come! (POLADMIN2-I; emphasis stressed by the speaker)

The following two citations illustrate, respectively, frontline workers' operational discretion (without performance pressures) and their focus on the individual situation instead of results:

[The cantonal department] does not prescribe us what we have to do. We are really free. The department finances us, but we are really free.

Int.: And you don't have success expectations or such prescriptions? Nor pressure in this sense?

No, not at all. (SLB2-II)

I am currently following a young woman... who has been with us for about 7 years. And...a lot has already happened there: beginnings, interruptions, beginnings....Now she is in her third apprenticeship year but it doesn't really look $100 \%$ good. Simply because of her....She has a child, she has very bad educational records, and then also her personality, and...simply all factors...I think she wouldn't have come that far if she hadn't had a reference person supporting her.

Int.: So, this shows that it is really the case, the individual result that is targeted?

Yes, you mean that we are client-oriented? We are only client-oriented. (SLB2-III)

Consequently, in this programme no Matthew-effectinducing incentive-structure was identified.

\section{Discussion and Conclusion}

Based on two in-depth embedded case studies of VET programmes for disadvantaged youth in Switzerland, the aim of this article was to offer deep insight into mech- anisms in this policy field which lead to a Matthew effect, and to contribute to the general understanding of this phenomenon in social policies. Discerning key actors' strategies against the backdrop of systems framing their possibilities for behaviour, two Matthew-effectinducing mechanisms were identified. First, in both cases, a Matthew effect is induced through the mandate of activating highly disadvantaged youth in selective markets, with eligibility criteria focusing on activation. While both policies are intended to support youth with complex needs throughout VET, none addresses the selective nature of the market. The centrality of activation on a selective market does not allow for the very disadvantaged to be reached: the most-disadvantaged are either excluded from the target group (Case 2) or strict eligibility criteria filters them out at the entrance to the programme because of their low chances to succeed (Case 1). Second, a cream-skimming-inducing incentive structure leading to a Matthew effect was identified in the first case. Even though it seems crucial for politico-administrative actors to contain a Matthew effect in in this policy field, the incentive structure driving frontline workers to cream-skim was deliberately embedded in the policy design by politico-administrative actors. This enabled attainment of politically satisfying results, safeguarding political and thus financial support for the measure. As both programmes represent last resort measures for disadvantaged youth, such Matthew effects lead to particularly detrimental consequences, hampering educational access and outcomes for the individuals in greatest need.

In both cases, a Matthew effect generally seems the result of a political compromise: to invest in highly disadvantaged youth despite a cost-containment context yet sacrificing the most-disadvantaged among them as apparently too cost-intensive. As noted by Bonoli (2017, p. 70), in times where political debates on the role of the state are dominated by budgetary restrictions induced by demographic aging, the credibility of the social investment strategy depends on its ability to demonstrate that the invested money produces returns. Indeed, as highlighted by Nadai, from an economic perspective, investment means the allocation of financial resources to realise monetary gain. Investments are therefore always selective, with disposable resources being directed to where biggest returns are foreseen (Nadai, 2017, pp. 80-81). To understand how the resources are channelled, it is crucial to know how returns are assessed, which is largely affected by the rationale underlying the social investment approach. Indeed, this concept is contended between different ideologies and interests. In terms of human capital investments, central to the social investment approach and to the present study, the underlying rationale can be of more economistic or of more social nature, inspired by the works of two highly different economists. First, a more economistic rationale, emphasizes the need of human capital investments for economic growth by increasing people's production possibilities. Highly influenced 
by economist James Heckman, who highlights the economic returns on investments in education (e.g., Heckman, 2006), this approach to social investment promotes human capital investments with the aim of increasing individuals' 'employability'. This notion emphasizes the individual's responsibility to become 'employable', while it neglects the importance of the socio-economic context into which individuals should integrate. Second, emphasising social returns from social investments, economist Amartya Sen takes a broader approach to human capital. Highlighting the multifaceted contribution of education to a person's life, he moves beyond economic growth as an end in itself, and emphasises the increased freedom to shape one's life which results from more education. This approach to social investment goes beyond the individual-centred notion of 'employability', highlights the importance of the socio-economic contextual framing, and seeks a stronger role of the state to shape the macroeconomic context to best accommodate the workforce (Morel \& Palme, 2017, pp. 150-153).

Both studied cases lean towards the first, economistic social investment approach: the focus is on converting the youth into more attractive apprenticeship-seekers, without interfering with the contextual framework of a selective market. This focus on employability implies that returns on investments are expected in activation terms. Consequently, the most-disadvantaged youth, far removed from the market, will not be considered as individuals worth investing in, due to low chances of returns on investment. If the emphasising were on social returns from human capital investments, returns would be assessed in terms of employability skills as a competence, in order to integrate on the long-term the demanding labour market of the knowledge society (Nadai, 2017, p. 80). The focus of the intervention would then be re-centred on the youth in difficulty and, thus, allow complex needs to be addressed. This would allow for value not only direct activation results, but also the necessary intermediary steps, potentially leading to the final activation objective, while improving the individuals' capacity to shape their own life. If returns on investment were assessed more generally, on the problems solved through the given service, while improving the inclusivity of the contextual framework, incidences of a Matthew effect would likely decrease. However, although it has been shown that net efficacy of education and training investments are higher for the most-disadvantaged individuals (Card, 1999, as cited in Esping-Andersen, 2017; Nicaise, 2000), in mature welfare states it seems that, to deal with permanent austerity, key actors move from the idealism of reaching out to the most-disadvantaged individuals, to the pragmatic, more cost-effective solution of focusing on those who are easier to reinsert into the market. Consequently, the most vulnerable individuals are subject to a vicious, further-marginalising cycle. Instead of correcting for previous inequalities these youth may have suffered (e.g., in school; Coradi Vellacott \& Wolter, 2005), such policies risk increasing them.

\section{Acknowledgements}

The author would like to thank the academic editors of this thematic issue Inger Lise Skog Hansen and Tone Fløtten, three anonymous reviewers, as well as Giuliano Bonoli, Fabienne Liechti and Anna Wilson for their valuable input on earlier versions of this article.

\section{Conflict of Interests}

The author declares no conflict of interests.

\section{References}

Amblard, H., Bernoux, P., Herreros, G., \& Livian, Y. F. (2005). Les nouvelles approches sociologiques des organisations [New sociological approaches to organisations]. Paris: Éditions du Seuil. (Original work published 1996)

Bell, D., \& Blanchflower, D. (2010). Youth unemployment: Déjà vu? (Working Paper no. 4705). Bonn: IZA DP.

Bonoli, G. (2013). The origins of active social policy: Labour market and childcare policies in a comparative perspective. Oxford: Oxford University Press.

Bonoli, G. (2017). L'investissement social dans la politique sociale en Suisse [Social investment in Swiss social policy]. In J.-M. Bonvin \& S. Dahmen (Eds.), Investir dans la protection social: Atouts et limites pour la Suisse. Reformieren durch Investieren? Chancen und Grenzen des Sozialinvestitionsstaats in der Schweiz [Investing in social protection: Strengths and limitations for Switzerland. To reform by investing? Opportunities and limitations of the social investment state in Switzerland] (pp. 66-78). Zürich: Seismo Verlag.

Bonoli, G., \& Champion, C. (2015). L'accès des familles migrantes défavorisées à l'accueil collectif préscolaire: Où et comment investir [The access of disadvantaged migrant families to collective preschool childcare: Where and how to invest]? Lausanne: Bureau cantonal pour l'intégration des étrangers et la prévention du racisme.

Bonoli, G., Cantillon, B., \& van Lancker, W. (2017). Social investment and the Matthew effect: Limits to a strategy. In A. Hemerijck (Ed.), The uses of social investment (pp. 66-76). Oxford: Oxford University Press.

Boston, J. (2013). Basic NPM ideas and their development. In T. Christensen, \& P. Laegreid (Eds.), The Ashgate research companion to new public management (pp. 17-32). Surrey: Ashgate Publishing. (Original work published 2011)

Braun, V., \& Clarke, V. (2013). Successful qualitative research. A practical guide for beginners. London: SAGE Publications.

Brodkin, E. (2012). Reflections on street-level bureaucracy: Past, present, and future. Public Administration Review, 72(November/December), 940-949.

Buffat, A. (2016). La bureaucratie de guichet ou les défis des contacts avec les usagers du service public 
[Bureaucracy at the counter or the challenges of public service users contacts]. In D. Giauque \& Y. Emery (Eds.), L'acteur et la bureaucratie au XXI siècle [The actor and bureaucracy in the 21st century] (pp. 141-167). Laval: Presses de l'Université Laval.

Camilleri-Cassar, F. (2013). Education strategy for social inclusion or marginalising the marginalised? Journal of Youth Studies, 17(2), 252-268.

Cantillon, B. (2011). The paradox of the social investment state: Growth, employment and poverty in the Lisbon era. Journal of European Social Policy, 21(5), 432-449.

Christensen, T., \& Laegreid, P. (2009). Introduction. In T. Christensen \& P. Laegreid (Eds.), Transcending new public management. The transformation of public sector reforms (pp. 1-16). Surrey: Ashgate Publishing. (Original work published 2007)

Christensen, T., \& Laegreid, P. (2013). Introduction. In T. Christensen \& P. Laegreid (Eds.), The Ashgate research companion to new public management ( $\mathrm{pp}$. 1-13). Surrey: Ashgate Publishing. (Original work published 2011)

Coradi Vellacott, M., \& Wolter, S. C. (2005). L'égalité des chances dans le système éducatif Suisse [Equality of opportunities in the Swiss education system] (Rapport de tendance no. 9). Aarau: CSRE.

Crozier, M., \& Friedberg, E. (2014). L'acteur et le système [The actor and the system]. Paris: Éditions du Seuil. (Original work published 1977)

Deleeck, H. (1979). L'effet Matthieu [The Matthew effect]. Droit social, 11, 375-383.

Dent, M. (2005). Post-new public management in public sector hospitals? The UK, Germany and Italy. Policy \& Politics, 33(4), 623-636.

Di Stasio, V. (2014). Education as a signal of trainability: Results from a vignette study with Italian employers. European Sociological Review, 30(6), 796-809.

Dif-Pradalier, M., Rosenstein, E., \& Bonvin, J.-M. (2012). Vocational training as an integration opportunity for struggling young adults? A Swiss case study. Social Work \& Society, 10(1). Retrieved from www.socwork.net/sws/article/view/303

Esping-Andersen, G. (2017). Chancengleichheit in einer zunehmend feindlichen Welt [Equal opportunities in an increasingly hostile world]. In J.-M. Bonvin \& S. Dahmen (Eds.), Investir dans la protection social: Atouts et limites pour la Suisse. Reformieren durch Investieren? Chancen und Grenzen des Sozialinvestitionsstaats in der Schweiz [Investing in social protection: Strengths and limitations for Switzerland. To reform by investing? Opportunities and limitations of the social investment state in Switzerland] (pp. 19-65). Zürich: Seismo Verlag.

Glaser, B. G., \& Strauss, A. L. (1967). The discovery of grounded theory. New York, NY: Aldine de Gruyter.

Gomel, B., Issehnane, S., \& Legendre, F. (2013). L'accompagnement et les trajectoires d'insertion des jeunes bénéficiaires d'un contrat d'insertion dans la vie sociale [The accompaniment and the insertion trajectories of youth benefitting from a social insertion contract]. Travail et Emploi, 134, 5-20.

Häfeli, K., \& Schellenberg, C. (2009). Facteurs de réussite dans la formation professionnelle des jeunes à risque [Success factors in vocational training of youth at risk] (Working Paper no. 29B). Bienne: EDK/ CDIP/CDPE/CDEP.

Heckman, J. J. (2006). Skill formation and the economics of investing in disadvantaged children. Science, 312, 1900-1902.

Hupka, S., \& Stalder, B. E. (2004). Achtung Gender. Ausbildungsverhalten von Mädchen und jungen Frauen: Trends und Tipps [Attention gender. Training behaviour of girls and young women: Trends and tips]. In Schweizerische Konferenz der Gleichstellungsbeauftragten (pp. 79-94). Bern.

Jun, J. S. (2009). The limits of post-new public management and beyond. Public Administration Review, 69(1), 161-165.

Liebig, T., Kohls, S., \& Krause, K. (2012). The labour market integration of immigrants and their children in Switzerland (Working Paper no. 128). Paris: OECD Publishing.

Lipsky, M. (2010). Street-level bureaucracy. Dilemmas of the individual in public services. New York, NY: Russel Sage Foundation. (Original work published 1980)

López Vilapana, C. (2013). Children were the age group at the highest risk of poverty or social exclusion in 2011 (Population and social conditions Working Paper no. 4). Luxembourg: Eurostat.

Meyer, T. (2009). Bildung: wer hat, dem wird gegeben [Education: Those who have, will receive]. Uni NOVA, Wissenschaftsmagazin der Universität Basel, 112, 10-11.

Morel, N., \& Palme, J. (2017). A normative foundation for the social investment approach? In A. Hemerijck (Ed.), The uses of social investment (pp. 150-160). Oxford: Oxford University Press.

Nadai, E. (2017). Investitionen in Ungleichheit [Investments in inequality]. In J.-M. Bonvin \& S. Dahmen (Eds.), Investir dans la protection social: Atouts et limites pour la Suisse. Reformieren durch Investieren? Chancen und Grenzen des Sozialinvestitionsstaats in der Schweiz [Investing in social protection: Strengths and limitations for Switzerland. To reform by investing? Opportunities and limitations of the social investment state in Switzerland] (pp. 79-92). Zürich: Seismo Verlag.

Nicaise, I. (2000). Formation des groupes défavorisés: Dilemme équité-efficacité [Training of disadvantaged groups: Equity-efficiency dilemma]? In V. Vandenberghe (Ed.), La formation professionnelle continue: Transformations, contraintes et enjeux [Continuous vocational training: Transformations, constraints and implications] (pp. 151-162). Louvain-la-Neuve: Academia Bruylant. 
Nicaise, I., \& Bollens, J. (1998). Training and employment opportunities for disadvantaged persons. In Vocational Education and Training. The European research field. background report (pp. 121-155). Thessaloniki: CEDEFOP.

Perriard, V. (2005). Transition de l'école obligatoire vers la formation professionnelle: Les facteurs explicatifs des difficultés actuelles. Analyse de littérature [Transition from compulsory to vocational education: The explanatory factors of current difficulties. Literature review]. Lausanne: Unité de Recherche pour le Pilotage des Systèmes Pédagogiques.

Pisoni, D. (in press). Activating the most disadvantaged youth: Administratively too risky, politically too costly? International Social Security Review.

Protsch, P., \& Solga, H. (2015). How employers use signals of cognitive and non-cognitive skills at labour market entry. Insights from field experiments. European Sociological Review, 31(5), 521-532.

Rankin, J., \& Regan, S. (2004). Meeting complex needs: The future of social care. London: Turning Point and Institute of Public Policy Research.

Rosengard, A., Laing, I., Ridley, J., \& Hunter, S. (2007). A literature review on multiple and complex needs. Edinburgh: Scottish Executive Social Research.

Salvisberg, A., \& Sacchi, S. (2014). Labour market prospects of Swiss career entrants after completion of vocational education and training. European Societies, 16(2), 255-274.

Staatssekretariat für Bildung, Forschung und Innovation. (2018). Berufsbildung in der Schweiz: Fakten und Zahlen 2018 [Vocational education and training in Switzerland: Facts and figures 2018]. Bern: SBFI.

Smith, S. R., \& Lipsky, M. (1993). Nonprofits for hire. The welfare state in the age of contracting. Cambridge, MA: Harvard University Press.

Solga, H. (2015). A fault confessed is half redressed. Review essay on low-achieving school leavers' access to apprenticeships and their returns to participation in prevocational training measures (Discussion paper no SP I 2015-501). Berlin: WZB Berlin Social Science Centre.

Stalder, B. E. (2012). School-to-work transitions in apprenticeship-based VET systems: The Swiss approach. In S. Billett, G. Johnson, S. Thomas, C. Sim, S. Hay, \& J. Ryan (Eds.), Experience of school transitions. Policies, practice and participants (pp. 123-139). Dordrecht: Springer.

Van Lancker, W., \& Ghysels, J. (2012). Who benefits? The social distribution of subsidized childcare in Sweden and Flanders. Acta Sociologica, 55(2), 125-142.

Yin, R. K. (2013). Case study research: Design and methods. Thousand Oaks, CA: Sage Publications. (Original work published 2009)

\section{About the Author}

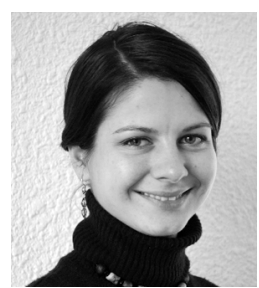

Delia Pisoni is finishing her PhD at the unit of social policies of the Swiss Graduate School of Public Administration (IDHEAP) in Lausanne, Switzerland. In her dissertation she focuses on the Matthew effect in vocational education and training programmes, and wishes to contribute to the general understanding of this effect in social policies. Her broader research interests include labour market access for disadvantaged individuals, vocational education and training access for disadvantaged youth, social work, and frontline practices. 